\title{
ONE NEW LOCALITY FOR THE ENDANGERED SPECIES ROUGHBACK WHIPRAY Fluvitrygon kittipongi (VIDTHAYANON \& ROBERTS 2005) (MYLIOBATIFORMES: DASYATIDAE) IN PENINSULAR MALAYSIA, BASED ON PHOTOGRAPHS
}

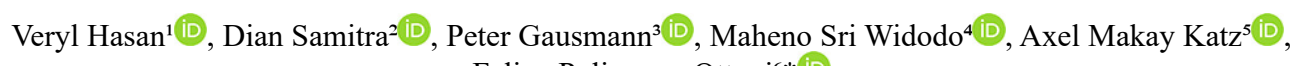
Felipe Polivanov Ottoni6* (iD)

${ }^{1}$ Aquaculture Department, Fisheries and Marine Faculty, Universitas Airlangga, Dr. Ir. H. Soekarno street, Surabaya, East Java 60115, Indonesia. E-mail: veryl.hasan@fpk.unair.ac.id

${ }^{2}$ Biology Education, STKIP PGRI Lubuklinggau, Mayor Toha street, Lubuklinggau, 31625, Indonesia. E-mail: dian. samitra@gmail.com,

${ }^{3}$ Landscape Ecology and Biogeography Department, Geosciences Faculty, Ruhr Universität Bochum, Universitätsstraße 150, 44801 Bochum, Germany. E-mail: peter.gausmann.2@googlemail.com

${ }^{4}$ Aquatic Resources Management Department, Fisheries and Marine Science Faculty Universitas Brawijaya, Veteran street, Malang, East Java 65145, Indonesia. E-mail: mahendo2019@gmail.com

${ }_{5}^{5}$ Laboratório de Sistemática e Evolução de Peixes Teleósteos, Departamento de Zoologia, Instituto de Biologia Universidade Federal do Rio de Janeiro, Cidade Universitária, CEP 21941-599. Rio de Janeiro, RJ, Brazil. E-mail: axelmk@gmail.com,

'Laboratório de Sistemática e Ecologia de Organismos Aquáticos, Centro de Ciências Agrárias e Ambientais, Campus Universitário, Universidade Federal do Maranhão, BR-222, KM 04, S/N, Boa Vista, CEP 65500-000,

Chapadinha, MA, Brazil. E-mail: fpottoni@gmail.com

*Corresponding author: fpottoni@gmail.com

\begin{abstract}
The Roughback Whipray Fluvitrygon kittipongi is a stingray species listed as "Endangered" according to the updated IUCN Red List. Until the year 2021, F. kittipongi was only known from five rivers in Southeast Asia, namely: Maekhlong and Chao Phraya River in Thailand, Pawan and Kapuas River in Borneo, Indonesia, and Musi River in Sumatra, Indonesia. It has been stated that this species also occurs in Perak River, Peninsular Malaysia, but without photographic records and an accurate confirmation of this occurrence. The most recent assessment (2021) by the IUCN Red List confirmed the occurrence of the species in Peninsular Malaysia based on one genetically identified specimen from the Perak River. However, the authors who evaluated this species for the IUCN Red List only stated that $F$. kittipongi was genetically identified, did not presenting any evidence (e.g., photographs, voucher number, a diagnosis or brief description of the specimen) or clear methodological information for the accurately identification of this unique specimen from Peninsular Malaysia. In this paper, we report a second locality for $F$. kittipongi in the region, providing photographs and a brief morphological description as evidence to confirm its occurrence. It is the first photographic record of this species for the region. This new record is based on two collected specimens, examined and photographed on 20 January 2019 from the Pahang River, Kuala Lipis, Peninsular Malaysia. The identification of this species confirms its presence in a new river basin, more than $150 \mathrm{~km}$ east from its previous record, in Peninsular Malaysia.

Keywords: Chondrichthyes, freshwater,threatened species, rays.
\end{abstract}

\section{RESUMO}

\section{Uma nova localidade para a espécie ameaçada de extinção arraia chicote de dorso áspero Fluvitrygon kittipongi (Vidthayanon \& Roberts 2005) (Myliobatiformes: Dasyatidae) na Península da Malásia, baseado em fotografias}

A arraia chicote de dorso áspero Fluvitrygon kittipongi é uma espécie listada como "Em perigo", de acordo com a Lista Vermelha da IUCN. Até o ano de 2021, F. kittipongi era conhecida apenas em cinco rios do Sudeste Asiático: Rio Maekhlong e Rio Chao Phraya na Tailândia, Rio Pawan e Kapuas em Bornéu, Indonésia, e Rio Musi na Sumatra, Indonésia. Existem evidências que esta espécie também ocorre no rio Perak, Península da Malásia, mas sem registros fotográficos e uma confirmação precisa dessa ocorrência. A mais recente avaliação (2021) da Lista Vermelha da IUCN disponível confirmou a ocorrência da espécie na Península da Malásia com base em um espécime geneticamente identificado do rio Perak. No entanto, os autores que avaliaram essas espécies para a lista vermelha da IUCN apenas afirmaram que $F$. kittipongi foi identificada geneticamente, não apresentando qualquer evidência (por exemplo, fotografias, número de comprovante, uma diagnose ou breve descrição do espécime) ou informações metodológicas claras para a identificação precisa deste espécime único da Península da Malásia. Neste artigo, relatamos uma segunda localidade para $F$. kittipongi na Península da Malásia, fornecendo fotografias e uma breve descrição morfológica como evidência para confirmar sua ocorrência. Este é o primeiro registro fotográfico dessa espécie para a região. Este novo registro é baseado em dois espécimes coletados, examinados e fotografados em 20 de janeiro de 2019 no Rio Pahang, Kuala Lipis, Península da Malásia. A identificação desta espécie confirma sua presença em uma nova bacia hidrográfica, a mais de $150 \mathrm{~km}$ a leste de seu registro anterior, na Península da Malásia.

Palavras-chave: Chondrichthyes, dulcícola, espécie ameaçada, arraias. 


\section{INTRODUCTION}

Several species of stingrays of the family Dasyatidae are known to enter or to live permanently in freshwater systems in Asia (Compagno \& Roberts 1982; Compagno \& Cook 1995). Most freshwater stingray's species have been listed under threat categories, due to their occurrence in restricted habitats often under overfishing pressure (Grant et al. 2019). One of them is the Roughback Whipray Fluvitrygon kittipongi (Vidthayanon \& Roberts, 2005). This species was described from the Maekhlong River, Thailand as Himantura kittipongi (Vidthayanon \& Roberts 2005). However, after the taxonomic revision of the family Dasyatidae by Last et al. (2016a), the species was moved to its current genus, Fluvitrygon Last, Naylor \& Manjaji-Matsumoto, 2016. This species is well known for its inherent vulnerability to population decline and collapse, with the major threats being habitat degradation throughout large areas of its known range, and capture by inland fisheries (Compagno 2005; Vidthayanon \& Manjaji 2016).

Until the year 2021, Fluvitrygon kittipongi was only known from five rivers in the Southeast Asia, namely: Maekhlong and Chao Phraya River in Thailand (Vidthayanon and Roberts 2005; Vidthayanon \& Manjaji 2016), Pawan and Kapuas River in Borneo, Indonesia (Last et al. 2010), and Musi River in Sumatra, Indonesia (Iqbal et al. 2018). It has been stated that this species also occurs in Perak River, Peninsular Malaysia, but without an accurate and photographed confirmation of this occurrence. Thus, its occurrence in Peninsular Malaysia was uncertain (Vidthayanon \& Manjaji 2016). Grant et al. (2021) considered the Threatened status of this species as "Endangered" according to the IUCN Red List guidelines. They also confirmed the occurrence of the species in Peninsular Malaysia based on one genetically identified specimen, which was recently captured in the Perak River (Grant et al., 2021). However, these authors only stated that the species was genetically identified, did not presenting any evidence (e.g., photographs, voucher number, a diagnosis or brief description of the specimen) or clear methodological information for the accurately identification of this unique specimen. In this paper, we report a second locality of $F$. kittipongi in Peninsular Malaysia, from the Pahang River, providing photographs and a brief morphological description as evidence to confirm its occurrence. The identification of this species confirms its presence in a new river basin, more than $150 \mathrm{~km}$ east from its previous record.

\section{MATERIAL AND METHODS}

Two specimens of F. kittipongi (c. $35 \mathrm{~cm}$ of Disc Width, female and c. 26 of Disc Width, male)
(Figure 1) were captured and photographed on 20 January 2019 in Pahang River, Kuala Lipis, Peninsular Malaysia (4¹1'39”N, $\left.102^{\circ} 05^{\prime} 48^{\prime \prime} \mathrm{E}\right)$ (Figure 2). These specimens were collected on the same location by local fishers using smallsized hook attached to line hands. The water was turbid and muddy, flowing slowly. After capture, morphometric data of both specimens were obtained, as well as some morphological characteristics were noted. Then, both specimens were released alive at the collection site, due to its populational restrictions and the IUCN Endangered Status. Diagnostic morphological characters and morphometric description of the specimens followed Vidthayanon \& Roberts (2005) and Last et al. (2010). Morphometric description of the specimens is provided in Table 1.

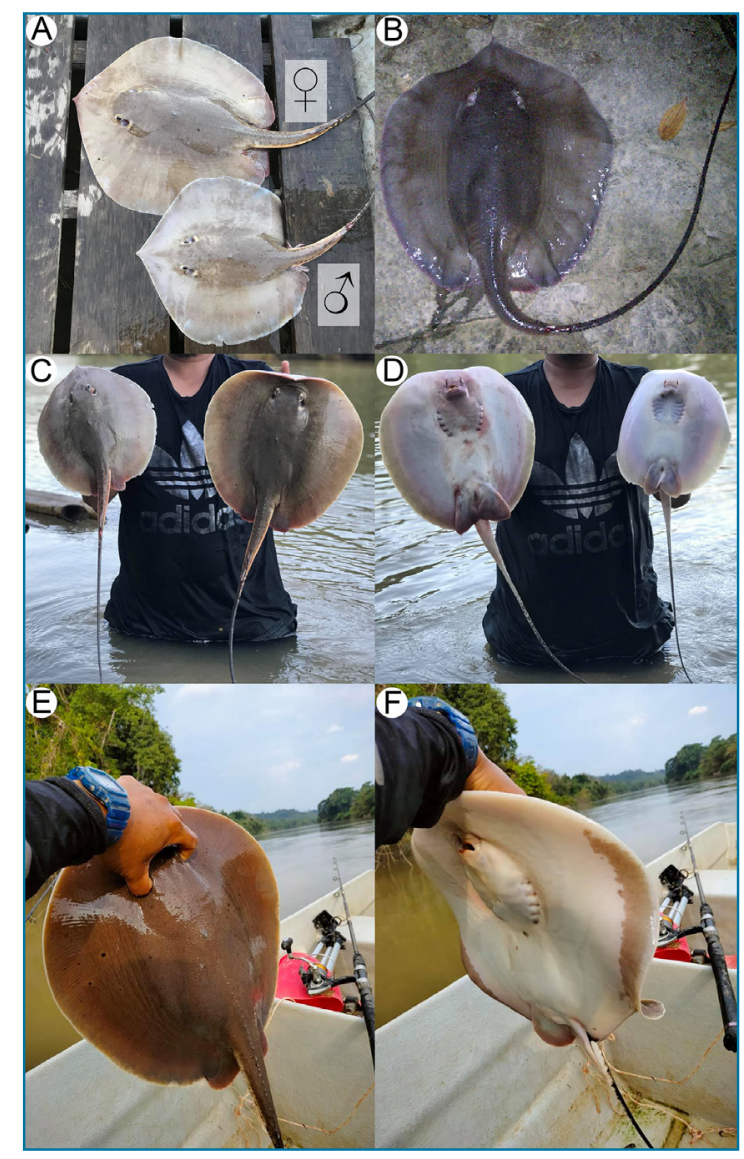

Figure 1.A) Dorsal view of F. kittipongi (female, $35 \mathrm{~cm}$ of Disc width, male, $26 \mathrm{~cm}$ of Disc width); B) Dorsal view of F. kittipongi (male); C) Dorsal view of F. kittipongi; D) Ventral view of $F$. kittipongi; E) Dorsal color pattern of F. kittipongi (male); and F) Ventralcolor pattern of F. kittipongi (male). Collected on 20 January 2019 in Pahang River, Kuala Lipis, Pahang, Peninsular Malaysia (Photograph: Mohd Iqbal). 


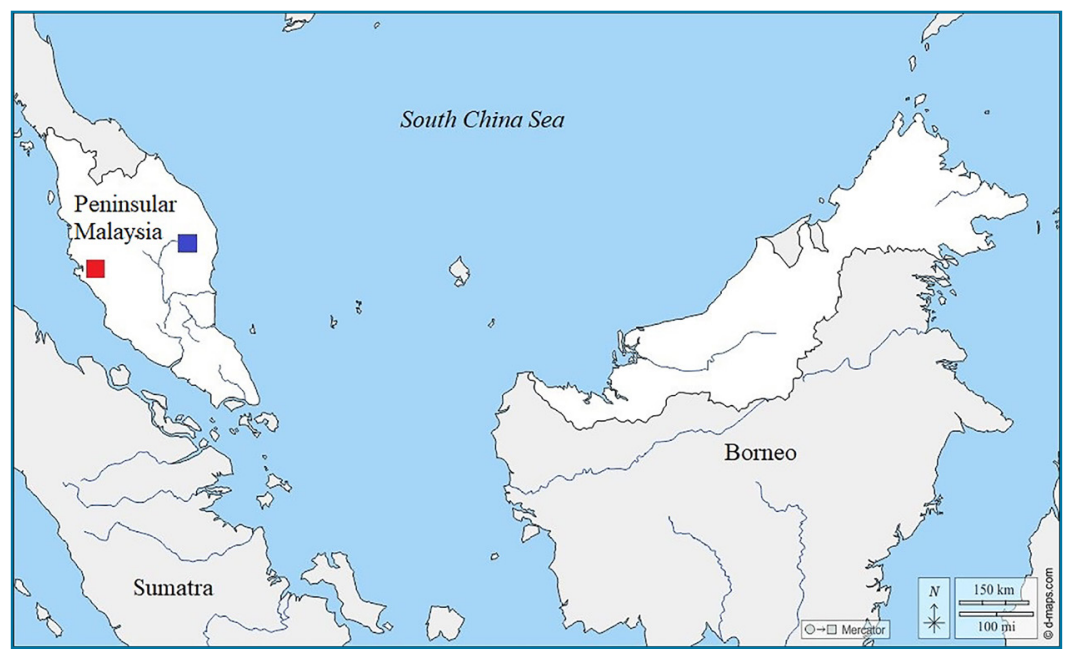

Figure 2. Records of F. kittipongi in Peninsular Malaysia. New record from Pahang River, Kuala Lipis, Pahang (blue square), and previous record from Perak River (red square) provided by Grant et al. (2021).

Table 1. Morphometric characters (in $\mathrm{cm}$ ) of the collected specimens of $F$. kittipongi.

\begin{tabular}{lcc}
\hline & \multicolumn{2}{c}{ Present study } \\
& Female & Male \\
\hline Total length & 110.0 & 95.0 \\
Disc width & 35.0 & 26.0 \\
Disc depth & 2.2 & 1.7 \\
Eye diameter & 3.7 & 3.6 \\
Interorbital width & 1.3 & 1.0 \\
Spiracle length & 7.5 & 7.5 \\
Mouth width & 10.0 & 9.5 \\
Snout tip-eye & 3.0 & 2.5 \\
Tail length & 75.0 & 69.0 \\
Sting length & 6.0 & 5.5 \\
Cloaca origin to sting & 12.0 & 11.5 \\
\hline
\end{tabular}

\section{DISCUSSION}

Both specimens that were captured in Pahang River, Kuala Lipis, Penisula Malaysia were identified as F. kittipongi by the following combination of characters: broad denticle band on the disc, single pearl thorn on the central portion of the disc, disc shape subcircular to oval with a short, sharply pointed tip; long tail with no skin folds on it, narrow-based, whip-like, not banded, with a row of slightly enlarged thorns in midline of the tail; small eyes. Coloration of fresh specimens: uniformly brownish at dorsal portion, whitish below with a broad dark outer margin (see Figure 1). These characters agree with the morphological characterization of $F$. kittipongi made by Vidthayanon \& Roberts (2005) and Last et al. (2010). Another congener with a similar body shape and external morphology which also occurs in the same kind of habitat and can be found in the same localities is F. signifer (Compagno \& Roberts 1982), reported in Peninsular Malaysia by Taniuchi (1979). However, both species can be easily differentiated by: the presence of a row of slightly enlarged thorns on midline of the tail, and ventral portion of the disc and the pelvic fins presenting a white coloration at the central region, with a dark marginal band beginning at about the anterior third of the disc and extending to its end, continuing across the pelvic fins in F. kittipongi; while $F$. signifer has no thorns in midline of the tail, and has a white marginal band at the ventral portion of the disc and pelvic fins (Vidthayanon \& Roberts 2005; Last et al. 2010).

Information on the extent of the Roughback Whipray's distribution and abundance is scarce. We present here the first accurately evidence of its occurrence, based on two photographed specimens, of F. kittipongi in the Pahang River, Kuala Lipis, Peninsular Malaysia, as well as we register a second location for the species in the region (Peninsular Malaysia). Actually, the present work is the first published photographic record and occurrence confirmation based on morphological inspection of F. kittipongi for Peninsular Malaysia, and therefore based on clear evidences. In addition to Malaysia, this species is officially registered to two other countries: Thailand and Indonesia (Last et al. 2010; Vidthayanon \& Roberts 2005; Iqbal et al. 2018). 
Among other biological topics, the new record of a rare non-marine elasmobranch is an important contribution to raise an understanding on the biogeography and species diversity of the Southeast Asian region (Hasan \& Widodo 2020; Hasan \& Islam 2020; Hasan et al. 2021). As reported in this paper, the new photographic record of F. kittipongi will contribute to improve the knowledge related to geographic distribution of the species. In the future, data collection assisted by local fishers is needed to assess the occurrence of $F$. kittipongi and evaluate the importance of rivers of Peninsular Malaysia as a crucial habitat for the species (Last et al. 2016b; Compagno 2002).

The Roughback Whipray is listed as Endangered (EN) on a global level by the IUCN Red List (Vidthayanon \& Manjaji 2016; Grant et al., 2021). Vidthayanon \& Manjaji (2016) and Grant et al. (2021) claimed that the occurrence of F. kittipongi in freshwater systems makes the species particularly vulnerable to human impacts and habitat modification. Similar to other regions in the Southeast Asia, habitat degradation in Peninsular Malaysia, such as removal of forest canopy leading to drought upstream and flooding downstream during monsoons, dam building, leading to silt build up and retention of agrochemicals behind impoundments and land development near rivers leading to the destruction of freshwater habitats, and run off pollution are all threats to the areas of occurence of this species (Compagno \& Cook 2005; Vidthayanon \& Manjaji 2016; Grant et al., 2021). Technical constructions like dam buildings and hydroelectric power stations represent potential threats for nonmarine elasmobranchs species like $F$. kittipongi and may prevent their upstream movement. These intensive human activities greatly affect the life cycle of several amphidromous fish such as bull sharks, freshwater eelsand sicydiinae gobies, and not only $F$. kittipongi (Arai et al. 2013; Hasan \& Widodo 2020).

Like other non-marine elasmobranchs species, F. kittipongi is not the main commodity of fisheries in Malaysia because few individuals are sampled, and this species is considered quite rare. There is no official record of how many $F$. kittipongi are caught because these fish are not a target species in Malaysia's commercial fisheries. Although F. kittipongi is not normally targeted, it is commonly caught by recreational fisheries, as well as retained for local consumption and aquarium hobby (Vidthayanon \& Manjaji 2016; Grant et al., 2021). The Malaysian government needs to strictly prohibit the practice of catching threatened freshwater stingrays, especially F. kittipongi.

\section{ACKNOWLEDGEMENTS}

We thank Pedro Bragança (South African Institute for Aquatic Biodiversity, South Africa) for the English language review; Mr. Mohd Iqbal and Mr. Nizam Zam for being our field guides; and Universitas Airlangga for funding our research. Finally, we thank Michael Grant (James Cook University, Australia) for sending useful literature.

\section{REFERENCES}

ARAI, T., CHINO, N. \& LE, D.Q. (2013). Migration and habitat use of the tropical eels Anguilla marmorata and A. bicolor pacifica in Vietnam. Aquatic Ecol., 47, 57-65.

COMPAGNO, L.J.V. (2002). Freshwater and estuarine elasmobranch surveys in the Indo-Pacific Region: threats, distribution and speciation. In: FOWLER, S.L., REED, T.M. \& DIPPER, F.A. (Eds.), Elasmobranch Biodiversity, conservation and management: Proceedings of the International seminar and workshop, Sabah, Malaysia, July 1997. IUCN SSC Shark Specialist Group, Switzerland and Cambridge, pp. 185-193.

COMPAGNO, L.J.V. (2005). Mekong freshwater stingray Dasyatis laosensis Roberts \& Karnasuta, 1987. In: S.L. FOWLER, M. CAMHI, G.H. BURGESS, G.M. CAILLIET, S.V. FORDHAM, R.D. CAVANAGH, C.A. SIMPFENDORFER AND J.A. MUSICK (eds), Sharks, Rays and Chimaeras: the Status of the Chondrichthyan Fishes. Status Survey, IUCN SSC Shark Specialist Group, IUCN, Gland, Switzerland and Cambridge, UK. pp. 347-348.

COMPAGNO, L.J.V., \& COOK, S.F. (1995). The exploitation and conservation of freshwater elasmobranchs: status of taxa and prospects for the future. In: OETINGER, M.I., \& ZORZI, G.D. (eds): The biology of freshwater elasmobranchs. Journal of agriculture and Aquatic Science, 62-90.

COMPAGNO, L. J. V. \& ROBERTS, T.R. (1982). Freshwater stingrays (Dasyatidae) of Southeast Asia and New Guinea, with description of a new species of Himantura and reports of unidentifi ed species. Environ. Biol. Fishes, 7, 321-339. https:// doi.org/10.1007/BF00005567

GRANT, M.I., KYNE, P.M., SIMPFENDORFER, C.A., WHITE, W.T. \& CHIN, A. (2019). Categorizing use patterns of non-marine environments by elasmobranchs and a review of their extinction risk. 
Rev. Fish Biol. Fish . 29, 689-710. DOI:10.1007/ s11160-019-09576-w.

GRANT, M.I, RIGBY, C.L., BIN ALI, A., FAHMI, HASAN, V. \& SAYER, C. (2021). Fluvitrygon kittipongi. The IUCN Red List of Threatened Species 2021: e.T161719A124533257.

https://dx.doi.org/10.2305/IUCN.UK.2021-2.RLTS. T161719A124533257.en

HASAN, V., GAUSMANN, P., NAFISYAH, A.L., ISRONI, W., WIDODO, M.S., ISLAM, I. \& CHAIDIR, R.R.A. (2021). First record of Longnose marbled whipray Fluvitrygon oxyrhyncha (Sauvage, 1878) (Myliobatiformes: Dasyatidae) in Malaysian waters. Ecol. Montenegrina, 40, 75-79. https://doi. org/10.37828/EM.2021.40.6

HASAN, V. \& ISLAM, I. (2020). First inland record of Bull shark Carcharhinus leucas (Müller \& Henle, 1839) (Carcharhiniformes: Carcharhinidae) in Celebes, Indonesia. Ecol. Montenegrina, 38, 12-17.

HASAN, V. \& WIDODO, M.S. (2020). Short Communication: The presence of Bull shark Carcharhinus leucas (Elasmobranchii: Carcharhinidae) in the fresh waters of Sumatra, Indonesia. Biodiversitas, 21, 4433-4439. https://doi. org/10.13057/biodiv\%2Fd210962

IQBAL, M., YUSTIAN I. \& ZULKIFLI H. (2018). The valid Species and Distribution of Stingrays (Myliobatiformes: Dasyatidae) in South Sumatran waters, Indonesia. Biovalentia, 4, 12-20. https://doi. org/10.24233/BIOV.4.1.2018.98
LAST, P.R., NAYLOR, G.J.P. \& MANJAJIMATSUMOTO, B.M.(2016a). Arevised classification of the family Dasyatidae (Chondrichthyes: Myliobatiformes) based on new morphological and molecular insights. Zootaxa, 4139, 345-368. https:// doi.org/10.11646/zootaxa.4139.3.2

LAST, P.R., WILLIAM, T.W., CARVALHO, M.R., SÉRET, B., STEHMANN, M.F.W. \& NAYLOR, G.J.P. (2016b). Rays of the world. Cornell University Press, Ithaca, viii $+790 \mathrm{pp}$.

LAST, P.R. \& STEVENS, J.D. (1994). Sharks and rays of Australia. CSIRO, Australia, $513 \mathrm{pp}+84$ pls.

LAST, P.R., WHITE, W.T., CAIRA, J.N., DHARMADI, FAHMI, JENSEN, K., LIM, A.P.K., MANJAJI-MATSUMOTO, B.M., NAYLOR, G.J.P., POGONOSKI, J.J. STEVENS, J.D. \& YEARSLEY, G.K. (2010). Sharks and rays of Borneo. CSIRO, Collingwood. 298 pp.

TANIUCHI, T. (1979). Freshwater elasmobranchs from Lake Naujan, Perak River, and Indragiri River, southeast Asia. Jpn J. Ichthyol., 25, 273-277. https:// doi.org/10.11369/JJI1950.25.273

VIDTHAYANON, C. \& MANJAJI, M. (2016). Fluvitrygon kittipongi. The IUCN Red List of Threatened Species 2016: e.T161719A104306749.

VIDTHAYANON, C. \& ROBERTS, T.R. (2005). Himantura kittipongi, a new species of freshwater whiptailed stingray from the Maekhlong River of Thailand (Elasmobranchii, Dasyatidae). Nat Hist Bull Siam Soc., 53, 123-132. 